September 2006

\title{
"When the Cannons Talk, the Diplomats Must Be Silent": A Danish Diplomat in Constantinople during the Armenian Genocide
}

\author{
Matthias Bjørnlund
}

Follow this and additional works at: https://digitalcommons.usf.edu/gsp

\section{Recommended Citation}

Bjørnlund, Matthias (2006) "'When the Cannons Talk, the Diplomats Must Be Silent": A Danish Diplomat in Constantinople during the Armenian Genocide," Genocide Studies and Prevention: An International Journal: Vol. 1: Iss. 2: Article 8.

Available at: https://digitalcommons.usf.edu/gsp/vol1/iss2/8

This Articles is brought to you for free and open access by the Open Access Journals at Digital Commons @ University of South Florida. It has been accepted for inclusion in Genocide Studies and Prevention: An International Journal by an authorized editor of Digital Commons @ University of South Florida. For more information, please contact digitalcommons@usf.edu. 


\title{
"When the Cannons Talk, the Diplomats Must Be Silent': A Danish Diplomat in Constantinople during the Armenian Genocide
}

\author{
Matthias Bjørnlund \\ Copenhagen, Denmark
}

\begin{abstract}
The envoy Carl Ellis Wandel was the sole Danish diplomatic representative in Constantinople before, during, and after World War I, and between 1914 and 1925 he wrote hundreds of detailed reports on the destruction of the Ottoman Armenians, as well as on related subjects. This article analyzes and contextualizes some of his most important reports, showing how these hitherto unknown sources contribute to the understanding of vital aspects of the Armenian Genocide, not least concerning the ongoing scholarly debate between "intentionalist" and "structuralist" interpretations of the event and concerning the destruction of the Ottoman Armenians as a particularly radical part of a Young Turk project of Turkification.
\end{abstract}

From the time of the Abdul Hamid massacres of 1894 to 1896 - the systematic annihilation of some 100,000 to 300,000 Ottoman Armenians, ${ }^{1}$ combined with the forced Islamization or displacement of several hundred thousands more ${ }^{2}$ - the persecution of this Christian minority had a significant impact on a broad range of leading public figures, as well as on the general public, in the Western world. ${ }^{3}$ This was also true in Denmark, where public figures raised awareness of the Armenian atrocities and their political implications through speeches, articles, books, and organizations: secular Danish-Jewish intellectuals Georg Brandes (1842-1927) and Age Meyer Benedictsen (1866-1927) exposed the indifference of the European governments to the sufferings of the Armenians ${ }^{4}$ and founded Danske Armeniervenner (DA, "Danish Friends of Armenians"), respectively, as a direct consequence of the massacres. ${ }^{5}$ From the other end of the spectrum, bishop and minister of cultural affairs H.V. Styhr (1838-1905), in 1897, denounced what he called Abdul Hamid's "holy war of extermination."6

Also, from 1900 onward, a number of Danish missionaries and relief workers went to work among Ottoman Armenians, in close cooperation with German, American, and Scandinavian colleagues, and some of these Danes became important witnesses to the extermination of the Armenians. One such person was Karen Jeppe (1876-1935), a schoolteacher and DA relief worker in Urfa from 1903-1919, who in 1921 became one of three members of the Commission of Inquiry for the Protection of Women and Children in the Near East from her base in Aleppo, Syria. This League of Nations commission was established in 1920 to deal with the problem of the tens of thousands of mainly Armenian women and children who had survived the genocide, many of them only to be forcibly converted to Islam, and were still kept in captivity in the

Matthias Bjørnlund, "When the Cannons Talk, the Diplomats Must Be Silent": A Danish Diplomat in Constantinople during the Armenian Genocide." Genocide Studies and Prevention 1, 2 (September 2006): 197-224. (C) 2006 Genocide Studies and Prevention. 
Turkish and Arabic areas of the former Ottoman Empire. ${ }^{7}$ Another such person was Maria Jacobsen (1882-1960), a missionary and nurse working for Kvindelige Missions Arbejdere (KMA, "Women Missionary Workers"), who was stationed in Harput (Kharpert) in the vilayet of Mamouret-ul-Aziz from the fall of 1907 until 1919. Both women witnessed every aspect of the Armenian Genocide-death marches, massacres, starvation, resistance, forced Islamization-from their respective geographical positions in the Ottoman Empire; and still, under these extremely difficult conditions, they managed to save the lives of literally thousands. ${ }^{8}$ Persons like Jacobsen and Jeppe were thus in an ideal position to give accurate accounts of the implementation of the genocide on the local and regional levels, but when it came to giving accounts of the overall political, economic, and ideological framework for the genocide, no Western observers was better suited than the diplomats in Constantinople.

\section{A Danish Diplomat in Constantinople: Carl Ellis Wandel}

At the outbreak of World War I in August 1914, Denmark declared neutrality. But, the fear among the government and the general population that Germany would occupy some or all of the small country as a preventive measure to secure access through the Danish straits led to the Danish neutrality policy toward Germany being declared "benevolent." It also had the effect of temporarily diverting interest from matters concerning, for instance, the plight of the Ottoman Armenian population some 2,000 miles away. But for Danes stationed in the Ottoman Empire during the war, the organized persecution of the Armenians was a tangible reality from the very beginning. One unknown, but important, Danish observer was Carl Ellis Wandel (1871-1940), who made up the entire diplomatic staff of the Danish legation in Constantinople (Istanbul) from 1914 to 1925.

Carl Ellis Wandel was born in Copenhagen and was commercially trained as a merchant in the family wine-importing business. When he was appointed minister (i.e., envoy) and head of the Danish legation in Constantinople in the summer of 1914, he was already an experienced diplomat. While running the family's wine cork factory in Lisbon, he had served as consul general in that city from 1904-1909, and when he moved to Argentina in 1909, he went within a few years from consul general in Buenos Aires to minister and full-time diplomat there until 1913, when it was decided that he should be transferred to the Ottoman Empire. ${ }^{9}$ Wandel took over the responsibility of dealing with official Danish relations from the Swedish legation, most likely as part of a drive for Danish trade interests in an area that was gaining increasing significance in Europe as a producer of raw materials as well as a purchaser of Western products. Judging by the hundreds of confidential reports he sent to the Danish foreign ministry from 1914 onward, now held in the Danish National Archives in Copenhagen, Wandel was a thorough and conscientious diplomat, analyzing the social and political developments in the Ottoman Empire in a knowledgeable, usually detached, and often very detailed way, with a constant eye to the possible effects these developments could have on Danish trade interests in the region.

What makes Wandel an especially important and credible witness to developments in the Ottoman Empire during World War I, including the Armenian Genocide, is a combination of several factors. First, he was a neutral observer from a neutral country-or, more precisely, a country whose government, not least its powerful foreign minister, Erik Scavenius, insisted on upholding the abovementioned 
"benevolent neutrality" toward neighboring Germany and her allies. ${ }^{10}$ Scavenius's general stance was to not blame anything on any of the warring parties, since he saw the war itself as an "uncontrollable machine that crushes everything." 11 He was certainly not a person to let potentially "controversial" considerations, such as a bias toward a persecuted minority in the Ottoman Empire, influence Danish foreign policy. In fact, when the Danish, Swedish, and Norwegian foreign ministries, through their respective royal courts, received an official request from the national Armenian delegation in Paris in April 1918 to intervene on behalf of the surviving Armenians in Armenia, who were being severely persecuted by Turkish troops following the withdrawal of the Russian army, the apparently unanimous answer from these neutral nations was that "nothing would be done."12

Second, Wandel's status as a diplomat from a "harmless" country (i.e., a small, neutral country without imperialistic ambitions) undoubtedly further enhanced his ability to gain the trust of the large number of influential political players he had access to. Apart from the obvious differences in economic and military strength, and therefore in diplomatic leverage, this status is somewhat reminiscent of the status of the United States in the Ottoman Empire before 1917. ${ }^{13}$ Also, most of Wandel's reports and analyses were confidential, and they were drafted with the purpose of giving accurate and reliable information to the Danish foreign ministry, a ministry that an experienced diplomat like Wandel is unlikely to have expected would actually be moved to make even a symbolic gesture toward the Ottoman Armenians or, for that matter, toward any other Ottoman minority. Neither did Wandel at any point suggest or expect that any action should be taken in this direction. Indeed, at one point he states in a report, "When the cannons talk, the diplomats must be silent." ${ }^{14}$ Unlike the legations of other then-neutral nations, such as the United States, Greece, and Bulgaria, ${ }^{15}$ the Danish legation does not seem to have been approached in the summer of 1915 by Ottoman Armenian representatives seeking diplomatic intervention on behalf of their fellow Armenians. But, Wandel agreed with his colleagues that only Germany, as the Ottoman Empire's most powerful ally, had the potential to significantly influence the Young Turks, although during the genocide he came to believe that the Young Turks had become so thoroughly radicalized that even a forceful German intervention could no longer help the Ottoman Armenians. ${ }^{16}$

This does not mean that Wandel was indifferent to the sufferings of the Armenians. On the contrary, as both a moral and a rational human being, he was highly affected by the genocide and wrote extensively about it in his reports, in which he could also, at times, point approvingly to objections raised by diplomats from other neutral countries against the persecutions of the Armenians. In his capacity as a diplomat, however, he adhered to strict neutrality. This was the case, when, in 1917, he was strongly urged by the American ambassador, Abram I. Elkus, Henry Morgenthau's successor, to protest against the continued persecution of the Ottoman Pontic Greeks living on the Black Sea coast. Wandel simply noted this fact in his report to the foreign ministry, and apparently neither he nor the ministry took any action. ${ }^{17}$

Also, even though Wandel was kept well informed of the increasing persecution and subsequent genocide of the Armenians by his connections in, for instance, the German, Spanish, Persian, Vatican, Dutch, American, and other embassies and legations, ${ }^{18}$ as well as in the Ottoman Turkish establishment, ${ }^{19}$ among missionaries from Denmark and other countries, ${ }^{20}$ and among Armenian and other Ottoman Christian circles, his reliability as a witness is further shown by the fact that he 
was not immediately ready to think the worst of the Committee for Union and Progress (CUP) regarding its policy toward the Armenians. During the summer of 1915, Wandel did realize that the Young Turk dictatorship had both the desire and the means to pursue its genocidal policy to its conclusion. But still, as shown below, it was not before 4 September of that year that he finally realized that the authorities would not stop short of a policy of outright extermination of the Armenian population. He came to this realization considerably later than most other Western observers, who had already recognized and reported this fact in June or July.

Best known are the reports from well-placed contemporary diplomats, missionaries, and rescue workers, such as the German theologian Johannes Lepsius, ${ }^{21}$ the German ambassador Hans von Wangenheim, ${ }^{22}$ and the American ambassador Henry Morgenthau. ${ }^{23}$ But also the very experienced Swedish ambassador to Constantinople, Per Gustaf August Cosswa Anckarsvärd, reported on 6 July 1915 that

The persecutions of the Armenians have taken on appalling proportions, and everything is pointing toward the idea that the Young Turks have wanted to take advantage of an opportunity where, for various reasons, no effective pressure from the outside needs to be feared to once and for all terminate the Armenian question. The method is simple enough and consists of the extermination of the Armenian nation. $^{24}$

This policy of extermination was a policy that, for Wandel and other observers, was not only cruel and unjust but also irrational, since they believed that the Empire would thus deprive itself of some of its ablest, most industrious, and best-educated citizens. ${ }^{25}$

\section{Background and Motivation for the Genocide: Ideology and the CUP}

One of the key points of disagreement in the historiography of the Armenian Genocide concerns whether the Young Turk policy of extermination was conceived for political, ideological, and/or economic reasons in advance of World War I or whether the actual decision was made mainly as a consequence of (incidents and radicalization related to) the war. ${ }^{26}$ This debate between what could be dubbed, in somewhat simplistic terms, "intentionalist" and "structuralist" interpretations is still ongoing. I will touch upon it only briefly here, but to me there is no doubt that scholars explaining the Armenian Genocide as the result of a mainly (but certainly not exclusively) "structural" process of cumulative radicalization have provided the most convincing interpretations, by which I mean simply that I have yet to see any truly convincing evidence that the physical destruction of the Ottoman Armenians had been planned before the spring or summer of $1915 .^{27}$

Two things must be stated concerning this debate, however. First, it is a purely academic debate, in the sense that the Armenian Genocide is of course a genocide whether it was decided upon years or months before World War $\mathrm{I}^{28}$ or as late as the spring or summer of $1915 .^{29}$ The destruction was profoundly intentional as opposed to, say, "accidental": real people were systematically and intentionally annihilated by other real people, not by faceless "structural forces." Second, the debate is not finished. The matter has yet to be settled, especially since it is generally difficult, and sometimes impossible, to decide whether increasingly genocidal actions during wars or revolutions are mainly the results of such events, premeditated results of atrocities committed under the cover of the events, or, as has become an increasingly more common interpretative model within genocide studies, a "twisted road" (i.e., the results of a dynamic combination of premeditation and circumstances). ${ }^{30}$ As in other cases 
of genocide, in the case of the Armenian Genocide more evidence and more sources need to be taken into consideration.

What "structuralists" as well as "intentionalists" do agree on is that it is clear that the radicalization of the Young Turk policy toward the non-Turkish minorities of the Ottoman Empire began not only before the outbreak of World War I but also before the Balkan Wars of 1912-1913. As early as 1908, the year of the Young Turk revolution, the CUP paper Tanin declared that "the Turkish nation is and will remain the ruling nation," 31 and in July 1910, a pro-Turkish, French-language journal based in Saloniki, Progrès de Salonique, wrote on the growing Japanese and Turkish nationalist movements that "at the head of these movements will be found the peoples belonging to the same race-the Mongolians. Each one possesses the unquestionable title to the moral and intellectual supremacy of the great countries over which their influence extends." 32

That same year, at the Young Turk congress in Saloniki, it was declared outright that the "Ottomanization" of the population of the empire-that is, the replacement of (for instance) a primarily ethnic Armenian identity with an Ottoman one-could not be achieved by persuasion but had to be achieved through forcible measures. ${ }^{33}$ And, according to the memoirs of the renowned Danish Orientalist and former rector of the University of Copenhagen, Johannes Østrup, at least one crucially important CUP member had simultaneously, before rising to the very top of the Young Turk hierarchy, expressed such distrust toward the Ottoman Armenians that he had called for their extermination. In 1937 Østrup almost casually recalls a series of business meetings with Mehmet Talât Pasha in 1910:

\begin{abstract}
It had really been Talat's plan to exterminate all of the Armenian people, and the plan did not originate as the result of a war psychosis. I spoke with Talât on several occasions in the autumn of 1910, and among many other things we also talked about the Armenians. "You see," he said, "between us and this people there is an incompatibility which cannot be solved in a peaceful manner; either they will completely undermine us, or we will have to annihilate them. If I ever come to power in this country, I will use all my might to exterminate the Armenians." Six years later he fulfilled his promise; the persecutions which were effectuated in the years of 1915 and 1916 cost-according to the lowest counts - the lives of more than 1.5 million persons. And yet one could not but like Talât; he was a barbarian or a fanatic, whatever one wants to call it, but his soul was free from deceit. ${ }^{34}$
\end{abstract}

It must be noted that Østrup, a conservative and a rather cynical realpolitiker who admired Kemal Atatürk as well as Talât, generally had no liking for either the Armenians or the Greeks of the Ottoman Empire, sharing as he did the popular prejudice among members of the Turkish elite, ${ }^{35}$ as well as among many European Orientalists and other observers at the time, that these peoples were "deceiving," "cowardly," and "mercantilist." This view was opposed to that of Turks, Kurds, and/or Arabs, who were often considered "pure" and "rural" and were thought to possess a more "warlike" spirit. ${ }^{36}$ Ottoman Armenians were a relatively well-educated, socially mobile minority, and, together with the Ottoman Greeks, they made up a comparatively large part of the empire's small middle class. Whereas some 70-80\% of the Armenians were in fact peasants, and many Armenian city-dwellers were relatively poor, they, like the Jews in Europe, were seen as the incarnation of the despised, Westernized "mercantile spirit." This view is illustrated in a contemporary account of the "racial" characteristics of Entente prisoners in German POW camps, in which Russian Armenians are described as being a "cunning race of merchants." 37 
At the same time, Armenians were also seen by Turkish nationalists as hindering the development of an ethnic Turkish mercantile class. ${ }^{38}$

But even though Ottoman Armenians were generally disliked and distrusted by many Westerners and Muslims alike, and even though, as Johannes Østrup recalls it, the main instigator of the Armenian Genocide desired their extermination as early as 1910, it does not follow that there was an actual Young Turk plan of genocide before World War I. It does suggest, however, that there is some truth in the notion shared by "intentionalist" scholars, such as Vahakn Dadrian, that a desire to seek a thoroughly radical solution, including extermination, to a perceived problem existed in influential Young Turk circles even before the beginning of the Balkan Wars. ${ }^{39}$ The loss of Ottoman territory, the massacre or forced migration of hundreds of thousands of Muslims from the Balkans and Caucasus, and the World War, with its instances of initial Turkish defeat, Armenian resistance, and so on, were most likely among the main events necessary to radicalize large parts of the Turkish establishment and population to such an extent that they were willing to carry out an overtly exterminatory policy against Armenians and other, mainly Christian, Ottoman minorities. But, a perhaps rudimentary, but certainly radical and influential, ideology that was just as necessary for traditional anti-Armenian sentiments to develop into a genocidal policy did already exist before these developments, as Wandel also points out (see below). ${ }^{40}$ As Taner Akçam has noted, Turkish nationalism came late compared not only to the nationalisms of Western Europe but also to the nationalisms of other Ottoman groups, and, like other "delayed nationalisms," it was aggressive and belligerent, determined to revive past glory and right perceived wrongs. ${ }^{41}$

Generally, whether or not one as a Western observer before World War I knew or believed that there was a radical segment of the CUP that desired a radical solution of the "Armenian question," the official Young Turk policy of creating a multicultural "Ottoman" identity instead of the various more or less developed national identities in the empire was regarded as unrealistic. Although some observers were, at least initially, optimistic to various degrees, others were much more cautious. ${ }^{42}$ The Norwegian KMA missionary in Mush, Bodil Biørn, though hopeful that the 1908 revolution would lead to reforms benefiting the Ottoman Armenians, was at the same time skeptical as to how such reforms would be implemented in a world ruled by "inequality, corruption, violence, and murder." ${ }^{33}$ In 1932, a member of the Danish KMA, Elise Bockelund, summed up in plain language the missionaries' view of the CUP revolution: "The Young Turk rule was a disappointment; they did not keep their promises, and, though they themselves were irreligious, they still gave preference to Islam, so the Armenians were not safe."44 Wandel exemplified the Young Turks' pre-war discriminatory policies by reporting that the electoral system was designed to discriminate heavily against Christians and that the authorities, despite their promises, did not want to give back Anatolian land to Armenians driven away during or after the Abdul Hamid massacres. ${ }^{45}$

A 1911 report from the Danish embassy in Rome analyzing the ongoing uprising in the Muslim Ottoman province of Albania points out that, in spite of the promises and stated ambitions of the Young Turks, there was a fundamental discrepancy between those ambitions and the political and ethnic realities of the Empire. According to the report, well-informed observers did not believe that the Young Turks would succeed in "fusing the various, differing elements of the population in the vast, loosely connected Turkish Empire into a truly Turkish nation," ${ }^{46}$ a view fully shared by the contemporary Turkist ideologist Yusuf Akçura. ${ }^{47}$ All the recent changes made by 
the Young Turks, which cut deeply into what the anonymous author(s) of the report describe as "the century-old habits of a completely immature population," would only bring confusion and rebellion throughout the empire. ${ }^{48}$ In 1913 , after the coup by the Triumvirate, the British foreign ministry even predicted that one of the consequences would be widespread massacres of Ottoman Armenians. ${ }^{49}$ There was a sense that the perceived problems with the non-Turkish national and religious minorities of the Ottoman Empire would eventually be "solved" in a violent manner. ${ }^{50}$ The question was when and how this "solution" would come about.

\section{Background and Motivation for the Genocide According to Wandel}

The most well-placed Danish observer of high-level Young Turk policy, Carl Ellis Wandel, tried in September 1915 to analyze how the Young Turk ideology had evolved from seemingly democratic Ottomanism to the current mix of xenophobia and extreme nationalism, a change he believed was partly ideologically and economically driven and, partly dictated by circumstances:

The CUP took the reins of power with a motto saying "equal rights for all Ottoman citizens." But to create the unity mentioned in the title of the Committee in the vast and ethnically diverse Empire, there had to be created a sense of Ottoman solidarity that included all the peoples of the Empire, while simultaneously guarantees had to be created that this new "Ottomanism" would also in the future be led by Young Turk members of the Committee; that is, at the same time creating equal rights for all Ottoman citizens, without regard to nationality and religion (the idealistic demands of the revolution), and making sure that this new Ottomanism would still be a purely Turkish movement. The struggle between these two demands lasted a while, until the Committee, immediately after the end of the Balkan War, resolutely discarded the first demand (equal rights for all Ottomans) and decided to pursue the road of Turkification, the road characterized by the boycott in the spring of 1914 that struck Greeks who were Ottoman subjects as well as Greek subjects, the simultaneous persecutions of Greeks in Asia Minor and Thrace, and, later that year, favoured by the World War and the subsequent annulment of the Capitulations [and] the declaration of Jihad-with German assistance-[Turkification] finally led to the xenophobic and nationalist policy, the recent consequences whereof I have several times closely examined, and which at the moment has as its main purpose the extermination of the Armenian population in the Empire. ${ }^{51}$

In the months after the 1913 coup, the new, more radical Young Turk leadership did try to give the appearance of continuing efforts to "Ottomanize" and centralize the empire in a peaceful and democratic manner. But, as Wandel and other observers have noted, if this had ever in reality been CUP policy, such was no longer the case. ${ }^{52}$ In fact, as Feroz Ahmad has put it, "repression and violence became the order of the day." 53 This process of radicalization Wandel considered so vital and intriguing that he made it the theme of a number of further reports. But, though he acknowledged that the extent of the radicalization was partly caused by events outside the control of the CUP, he also emphasized that radicalization was not simply the result of various defensive ad hoc measures against, say, Western imperialism, but was in fact an integral part of an active, deliberate policy, rooted in pre-revolutionary Turkist supremacist beliefs, whose basic goal was the preservation of power.

Since it was no longer believed that this goal could be reached by a multiethnic, multireligious, Turkish-dominated union, it would be reached by somehow creating a "Turkey for the Turks," economically, politically, linguistically, and ethnically, increasingly combined with the more expansionist Pan-Turkist vision of Turan, 
a Turkish Empire uniting ethnic Turks from all over Asia and Russia. ${ }^{54}$ In a report from 22 September 1915, Wandel accordingly describes the nature of the CUP by describing the members of the CUP

not as great idealists or founding statesmen but as organizers using every means to further their organization ... It is not the ideals, but the frame, that is, the power, that they have fought and are fighting for.... For some there is no doubt about their integrity, but it is the general understanding that [the CUP] will continue to pursue the policy it has already initiated, a policy which has led to so many conflicts.

Wandel believed, mistakenly, that this policy would eventually lead to "national suicide." 55 In fact, though the costs were immense, it was an important initial step leading to the creation of the relatively homogeneous, if unstable, nation-state that is the modern Turkish Republic. ${ }^{56}$

But, as Wandel also emphasized, even though the Young Turks generally were not "great idealists," they did share some broad ideals-ideals that, if nothing else, served to legitimize their own power monopoly in particular, and the power monopoly of ethnic Turks in general, as well as serving to secure the centralization and homogenization of a disintegrating empire. ${ }^{57}$ The nation, beginning with the areas of trade and language, was to be cleansed from what were deemed to be "foreign elements" in order to establish the desired national culture and economy. ${ }^{58}$ Thus began the systematic, still ongoing process of nation building by marginalizing or destroying the non-Turkish components of, first and foremost, the age-old Anatolian multicultural make-up, a process that required both the rewriting of history and the definition of non-Turks as the "Other." 59

In a lengthy report from January 1915, titled "Political Events in Turkey in 1914," Wandel describes how it was only after the Young Turk dictatorship had come to power that one could see Turkish shops in Constantinople advertising that "This Is a Muslim Business." 60 The fact that, according to the Danish diplomat, the Armenians and Greeks of the Ottoman Empire were at this point generally wary but loyal even toward a dictatorship made no difference. Already on 24 July 1914, Wandel had reported that "the Christian electorate is generally opposed to the CUP's favored system of centralization and to the principle 'Turkey for the Turks,' but when it comes to improving their living conditions, they see it as necessary to work with the Committee, rather than to break with it." 61 This despite the fact that the Christians of the empire were subjected to what Wandel describes as a repressive and xenophobic regime that systematically discriminated against them. ${ }^{62}$

On 6 December 1915, Wandel elaborated on how the CUP elite and Turkish intellectuals had increasingly become radical nationalists. Apart from pointing to the genocide itself, his report exemplifies this by mentioning the preceeding attempted "cleansing" of Greeks from Western Anatolia and of Greeks and Armenians from politics and trade; the government-controlled, xenophobic press; the nationalist schools" and the ban on street signs and so on written in "foreign," that is, non-Turkish, languages. ${ }^{63}$ Wandel refers in this report to an article in the Turkish daily Tesfiri Efkiar from 11 November 1915, which emphasized that

the Turkish language is the foundation of our national development. At the moment we are engaged in a war for our very existence, and the first result of this victorious war ought to be that it is confirmed that the Turkish language reigns supreme in Turkey. ${ }^{64}$

Furthermore, in what Wandel dubbed the "Germanized-chauvinistic" Turkish press, Armenians were often described as "greedy exploiters" by journalists 
who willingly participated in the forefront of the regime's xenophobic campaign. ${ }^{65}$ One such example was Agaoglu Ahmed Bey, the editor of the French-language Young Turk daily Hilal, which functioned mainly as a propaganda organ in the West, as well as among Westerners in the Ottoman Empire. Ahmed Bey, who had "Turkified" his name Ahmed Agaieff, thus hiding his Azeri (Tatar) background, was a Turkist ideologist who, according to Wandel, had long been known for his extreme hatred of Armenians as one of the organizers of massacres of Armenians in the Caucasus in 1905. ${ }^{66}$ Leading Young Turks even went so far as to openly describe Armenians and other Ottoman Christians as "tumors," a cancer that had to be removed so that the Turkish nation could be "cured." 67

For Wandel, as well as for other observers, it was obvious that the economic and linguistic discrimination, together with other official discriminatory and repressive initiatives, created a society without room for opposition or minorities. These initiatives included the establishment of a nationwide, Turkish-nationalist, militarized "scout movement"; the establishment of ethnic Turkish transport and trade companies; and the calling out of Turkish schoolchildren and workers to celebrate newly created national (i.e., exclusively Turkish) commemoration days and celebrations. ${ }^{68}$ Although Wandel was rightfully doubtful whether these "nationbuilding" initiatives actually had any significant impact on the general population, for the Young Turks this whole process, and its acceleration during the war, was part of the Turkish people's “wonderful awakening, which the government has long been struggling to bring about, and which had to come sooner or later, but which has now been accelerated by the war," as the otherwise moderate vali of Adrianople (Edirne), Hadji Adil Bey, expressed it in a speech given in his capacity as speaker at the opening of parliamentary sessions in the Ottoman Chamber of Deputies in November $1916 .^{69}$

The deliberate and "rational" nature of this Young Turk nationalist ideology was also clearly expressed by the experienced diplomat Djevad Bey, Turkish minister to Copenhagen and a diplomate de carrière with close connections to the Young Turk government. In an interview given to leading Danish newspaper Politiken in February 1916, he stated that

We have now introduced the Turkish language in Turkey. This is the first result of a national awakening: Turkey for the Turks.... When we change old signs and street names, our enemies claim that we tear down the European inscriptions out of hatred and malice. There is no truth in that. We only do what all nations have done before us. They call us chauvinists and rebels. I assure you, we only want one thing: our economical and political independence. This we all agree upon. There are no longer both old and young Turks. There are only Turks. And during the war we are all young. ${ }^{70}$

Paradoxically, chauvinist Turks had come to believe that in order to become truly "European"-perceived as being effective, competitive, homogenic, assertive, powerful, expansive, rich, modern, and so on-they must eliminate the perceived European elements of the Empire, that is, the Ottoman Christians, who had become an obstacle to reaching this goal. The fact that, by targeting Christians, the Young Turks also pleased the conservative, Islamist opposition was, according to Wandel, another, more opportunistic reason for this policy. ${ }^{71}$

It is contested whether the ideology of a "Turkey for the Turks" can be directly related to the subsequent "cleansing" and massacre of Ottoman Armenians and other minorities, or whether the Armenian Genocide in particular was, rather, 
a "perverse and extreme security measure based in an ethnoreligious framing," as Ronald Grigor Suny expresses it. ${ }^{72}$ To me, first, these explanations are not mutually exclusive; rather, they complement each other, showing the "twisted" (i.e., ideological and deliberate as well as circumstantial and opportunistic) nature of the Armenian Genocide. Second, the reports Wandel sent to his superiors in Copenhagen help underline that no matter the circumstances, the extremely chauvinist ideology of the Young Turks was a main reason that, from the outbreak of World War I, the Armenians immediately and violently came to be "ethnoreligiously framed." Because of the paranoid fear expressed by Talât that the Armenians as former allies knew, and therefore could destroy, the Young Turk organization, and the fact that many Armenians lived near the front lines in Eastern Anatolia, Armenians were perceived, both before and during the war, to be the most dangerous internal threat. ${ }^{73}$

The war itself was most likely a crucial factor leading to the decision in favor of genocide, as it gave rise to both the opportunity of "settling scores" and the need for a scapegoat to divert criticism for the initial losses of the Ottoman army. The war also resulted in atrocities against Muslim civilians, as well as in scattered Ottoman Armenian nationalist activity and resistance that, through official campaigns of propaganda and misinformation, served to further legitimize, brutalize, and dehumanize. In 1915, if not before, the Turkish national identity was influenced by the loss of territory and prestige to an extent that resulted in a willingness to use exterminatory measures against those societal groups who were now thought to be threatening not only the traditional hegemony of ethnic Turks but the very survival of the Turkish nation. ${ }^{74}$ This Young Turk "siege mentality" was heightened by the fact that Turks were themselves still a minority among minorities- the Kurds, Arabs, Armenians, Greeks, Assyrians, Jews, Circassians, and other groups of the Ottoman Empire.

But the cleansing from Ottoman soil of Armenians became not only a goal in itself but also an integral part of a grand project to create a Turkish nation. The regime initiated the above-mentioned simultaneous measures ("national holidays," etc.) aimed at imprinting a Turkish national identity upon the large majority of the Turkish population that had traditionally identified themselves mainly along (ethno-)religious lines. ${ }^{75}$ But the removal of potential challenges to Turkish hegemony was believed to be a precondition for these "positive" measures to succeed, as expressed by Wandel in March 1916:

If the Young Turks have their way, the time will never come back when the Arabs, Armenians, and Greeks made up the majority in the Ottoman parliament, because they realize that such a majority sooner or later would demand that the Caliphate be replaced by a confederation, and that they would soon lose their power. The Turks have therefore chosen the only means available to them to preserve their control over Turkey-which is the complete extermination of the peoples who had the greatest possibilities to evolve after the introduction of the constitution, and with whom they have no way of competing in a peaceful struggle. ${ }^{76}$

\section{The Persecution of the Ottoman Greeks in 1914: The Beginnings of Violent Turkification}

Before the outright exterminatory policies of World War I were initiated, the first attempts at violently homogenizing the ethnic and religious make-up of Anatolia had already begun. In the spring and summer of 1914, when attempts at removing 
non-Turkish influences from the Ottoman economy had just been initiated in earnest, this policy was supplemented with the "cleansing" and massacre of more than 100,000 ethnic Ionian Greeks from the Aegean region. ${ }^{77}$ This was the result of careful deliberations and preliminary research by the CUP, accompanied by a decision to hide the connection between the government and the Special Organization, the organization in charge of the operation. ${ }^{78}$ This conclusion is confirmed by a June 1914 report to Wandel from the Danish consul in Smyrna (Izmir), Alfred van der Zee, that a large-scale, systematic, and violent banishing of what he, Van der Zee, describes as the generally very peaceful Greek population was carried out on the orders of the central government. $^{79}$

According to Van der Zee, in March 1914, the valis of Smyrna and the nearby regions had made tours of inspection to the coastal towns and villages of the vilayets, "advising" the local civil servants to force the Greek population out, first by economic boycotts, then, when this did not have the desired effect, by violent persecution: "Armed 'bashibozuks' [Turkish irregular troops] attacked the Greek population, raped the Greek women, killed the children, etc. Finally, the gangs also violated non-Ottoman citizens." 80 These bashibozuks, alternatively called "Turkish gangs" in the reports, numbered 8,000 to 10,000 in the vilayet of Aidin (Smyrna) alone and were financed and run by the state. Many of these gangs consisted of members of the Special Organization and/or Muslim refugees from the Balkans or the Caucasus, the so-called muhadjirs, who, according to Wandel, carried out the persecutions, plundering and murdering "as many of the hated Greeks as possible." 81 Aside from economic, ethnic, and political motives, there was a military rationale behind this policy, in the sense that the Young Turk government wanted to prevent the Greeks along the coastline from eventually becoming as a fifth column, a danger believed to be particularly imminent because Greece had come to control the nearby islands of Chios and Mytilene, which, it was claimed, could be used to launch attacks. ${ }^{82}$

Despite attempts to keep this policy a secret, and despite attempts to deny both the existence of and the responsibility for the policy, the Young Turk government soon had to change course, facing pressure from, especially, the French government. The Young Turks were also aware that they were not ready for the war with Greece that would most likely result if the persecutions did not stop. ${ }^{83}$ But after consultations with the Austrio-Hungarian ambassador to the Ottoman Empire, Count Johann Pallavicini, Wandel was convinced that a war between Greece and the Ottoman Empire was bound to break out soon and that the Greek population of Anatolia would then "be worse off than ever before." ${ }^{4}$ This prediction was accurate, since, during World War I, the persecutions of the Ottoman Greeks were taken up again on a regular basis, sometimes on German initiative, and hundreds of thousands of Greeks from Anatolia and Thrace, including the Pontic Greeks from the Black Sea coast, were either killed or expelled from 1914 through 1918. In June 1917, too, Greece did join the war against the Ottoman Empire and her allies. ${ }^{85}$

In 1914, the aim of this policy was most likely not to exterminate but, as it has been put, to "thin out" (and thereby significantly weaken) the Ottoman Greek population, as an extension of the policy of economic and cultural Turkification, while at the same time creating living space for the muhadjirs. ${ }^{86}$ This policy was, as stated above, not only economically but also politically and ideologically motivated. Whatever the rationale, it was a cruel and murderous policy. As Wandel expressed it, the losses 
resulting from the persecutions were obviously irreparable, since "an industrious class of people have been expelled, despite the fact that the province was already thinly populated. It can be predicted that the province will suffer from the results of this failed policy for years to come." 87 But the practical experiences, the impunity of the perpetrators, and the relative political "success" of the persecutionsthousands of Greeks fleeing in terror, leaving their homes and possessions to be taken over by Muslim refugees ${ }^{88}$ - meant that even more radical and violent measures during World War I could be seen as not only possible but also as yet another extension of a policy of "social engineering" already decided upon. Besides, as Talât told Morgenthau during the Armenian Genocide, "We care nothing about the commercial loss." 89

For the Young Turks, one of the major advantages of such a policy of homogenization was that the Western powers, particularly Britain and Russia, would be presented with a fait accompli, in that the mainly Christian groups would be gone, groups that historically had served as an excuse for these powers to interfere with what the Young Turks regarded as the internal matters of the Ottoman Empire. The persecutions of the Greek minority from 1914 onward therefore point toward an actual policy of extermination, if not in the sense that these policies were planned to be continuous parts of a "grand scheme" of partial and total genocides (see note 86), then certainly in the sense that both policies were the result of xenophobic deliberations that were inherently genocidal and in the sense that the two policies were closely connected, ideologically, politically, and bureaucratically. ${ }^{90}$ This connection is perhaps most strikingly personified by the decidedly racist founding member of the CUP, Dr. Mehmed Reşid. In 1914, as mutasarrif (governor) of the sub-province Karesi in the province of Balikesir, he was heavily involved with the persecution of the Aegean Greeks, while as vali of Diyarbekir he was responsible for the extermination of the Armenians and Assyrians in that region in 1915 and $1916 .^{91}$

With respect to the developing Young Turk policy of denial, official reactions to the 1914 persecutions also point forward toward a vital aspect of the early denial of the Armenian Genocide-the claim from Constantinople that the central government, when it came to outright killings, had no control of the regional governments or of the designated killer gangs. The interior minister, Talât Pasha himself, declared in June 1914 that the occurence of what he called "regrettable incidents" in the Smyrna region was because "many Turkish civil servants in the provinces still believe that the orders they receive from the imperial government in Constantinople [to protect the Greek population] have been issued under pressure from the Great Powers, and therefore not issued in earnest." 92 Therefore, according to Talât, all responsibility for wrongdoing rested with the vali of Smyrna. The interior minister even went on what Van der Zee calls a farcical tour of the Smyrna region, traveling from city to city, making speeches promising "complete security," while the local Greeks had to stay at home, day and night, to avoid being beaten up or shot. ${ }^{93}$

There are clear indications that while the persecutions of the Ottoman Greeks was the first major step toward the ethnic, religious, and economic Turkification of the Empire, and the genocide of the Armenians the most important and radical such step, other steps were planned or desired-for instance, concerning the Ottoman Jewish minority. By December 1914, hundreds of Jews had been deported from Jaffa in Palestine to Egypt before this particular operation was stopped because of concerted 
protests from ambassadors Morgenthau and Wangenheim. It is believed that the Ottoman authorities generally distinguished between Jewish nationalists and the general Jewish population, perhaps as a result of such external pressure. ${ }^{94}$ But Wandel and other observers, including some Ottoman Jews, were convinced that the process of Turkification was meant by the Young Turks to be total. For instance, on 16 November 1915, Welsh MP Aneurin Williams stated during a parliamentary debate on what was called "the Armenian atrocities" that "it is not only Christians. Apparently this process of exterminating all the progressive elements of the countrywhat is called Ottomanising the country-extends far beyond the Christians. The Zionist Jews, for some reason, have been suspected of being an enlightening force, and they, too, have been in terror." 95 Similarly, Wandel stated that "the goal of the Zionist movement can...hardly be reconciled with the policy of the present Turkish government, which aims at removing from Turkey all foreign elements." ${ }^{96}$ It was feared that the policies of extermination and/or deportation would, if unchecked, sooner or later come to include the Ottoman Jews, even though, according to Wandel, this group was generally known to be particularly "well integrated" into the Turkishdominated Ottoman society. ${ }^{97}$

The massive deportations of Ottoman Kurds in 1916-1917 are yet another indication that the ideology of a "Turkey for the Turks" was to be realized to the fullest possible extent and that the homogenization of Anatolia was the result of a bold, criminal, highly organized, and deliberate policy. Though there are many examples showing that, during the genocide, Kurdish tribes and individuals (as well as many other Muslims) did help Armenians hide or escape from the Turkish authorities, ${ }^{98}$ generally, Kurdish militias and villagers played a significant role as executors of the genocide. But when the vast majority of the Armenians had been cleansed from Anatolia, the Young Turks began concentrating on what they regarded as the no less troublesome Kurds.

Since it was believed that it was generally possible to assimilate Muslim minorities, ${ }^{99}$ the Kurds were not systematically massacred but, rather, were deported to the western parts of Anatolia to be forcibly assimilated among ethnic Turks, who now began to constitute the majority in cities and regions, quite often thanks to the "disappearance" of the Ottoman Christians. Still, tens of thousands of Kurds were killed outright, and hundreds of thousands died of diseases and starvation ${ }^{100}$ and they were not the only Muslim Ottoman citizens being persecuted. In 1918, George E. White, in an article titled "Some Non-conforming Turks," wrote that

Those rumors of impending events in Turkey, which anticipated the deportation of Armenians and similar treatment for the Greeks and other Christians of the Empire, carried the foreboding that the next step taken by the governing clique would force the Alevi Turks to abandon their Moslem nonconformity. The purpose of the "Party of Union and Progress" is alleged to be to create a uniform state, one in Turkish nationality, and one in Moslem orthodoxy. ${ }^{101}$

\section{From Persecution to Total Genocide: The Report of 4 September 1915}

Back in August 1915, as shown above, Wandel was still hoping that the CUP would not remain what he considered to be so daring and irrational as to take its chauvinist and xenophobic policy-the massacres and persecution, the forced conversions to Islam, and so on, which it pursued, as Wandel stated, under the pretext of 
"military necessity"102 — to its final conclusion, which would be the extermination of the Armenian population in the Ottoman Empire:

In my earlier reports, it has already been stated how the Young Turk government, with the aim of strengthening its position internally, lately has made xenophobia and hatred toward Christians a leading principle in its policy.... The aim of this policy is to force foreigners and Christians to leave the country by making their existence in Turkey intolerable, thereby at the same time satisfying the fanaticism that has become an asset for the government, but it is of course not possible to speak of the rational completion of this policy, at least not concerning the Greeks .... For Turkey's own sake it is probably about time that the persecutions are stopped. The fanatical Committee complains that there is no patriotism in Constantinople, which it wants to transform into a Turkish-Muslim capital, but it does not seem to realize that it makes a big mistake in driving out the foreigners and the Christians, even seen from an academic point of view, since it thereby drives out the entire intelligence of the country, the entire part of the population that is in possession of spirit, insight, and means, the businessmen, the scientists and the financiers, and that, if the principle of "Turkey for the Turks" is to be carried through, there will be nothing but civil servants and peasants in the country. ${ }^{103}$

But on 4 September 1915, less than three weeks after he had expressed his almost desperate hope that the CUP would stop short of outright extermination, Wandel for the first time informed his superiors in the Danish foreign ministry that a genocide was indeed taking place:

I will briefly allow myself to give an account of the important and sad information regarding the latest developments that has been given to me by a completely trustworthy and truthful source, and which is of such a nature that it will be regretted everywhere in the Christian world. The Turks are vigorously carrying out their cruel intent, to exterminate the Armenian people. ${ }^{104}$

This was not just a statement. Wandel backed it up by giving numerous examples of the nationwide "evacuation" of Armenians, a euphemistic expression that, he emphasized, meant almost certain death by organized massacres and deprivation. ${ }^{105}$

For example, Wandel had received a letter from the Armenian Catholic bishop of Erzerum, Joseph Melchisedechian, who informed him that the parish of Khodirtchour, which consisted of twelve villages, had been completely evacuated, and that no one knew what had happened to the vanished Armenian population. ${ }^{106}$ The Armenian Catholic bishop of Harput, Stepan Israelian, had on 23 June informed the Patriarchate that he had received orders to leave the city for Aleppo with the whole of his congregation within twenty-four hours. Later it was discovered that Israelian and approximately 1,700 other Armenians had been attacked and killed on the road between Diyarbekir and Urfa. ${ }^{107}$ Wandel's report furthermore mentions that the archbishop of Mardin, Ignatius Maloyan, had been killed, together with approximately 700 Catholics from the congregation; that the Catholic population of Tel Armen had been wiped out completely; that the cities of Tarsus, Hedzin (Hadjin), Mersina (Mersin), and many others had been "completely evacuated"; and that Armenian women of Angora (Ankara) had been forcibly married to Muslims, while approximately 6,000 deported men, among them seventy clergy led by Bishop Gregoire Bahaban, had been shot. ${ }^{108}$ In that same report, Wandel states that "even here in Constantinople Armenians are kidnapped and sent to Asia, and it is not possible to get information of their whereabouts." 109 He ends the report by concluding that "the fate that has befallen the Catholic Armenians has with even greater cruelty befallen all other 
Armenians, as the intention of the government, as I already have had the honour to report, is to completely annihilate the Armenian people."110

As for the significance to the extermination project of the question of "Armenian loyalty"-in itself a rather meaningless phrase, since it implies some sort of general Armenian organization, mindset, and pattern of actions that did not exist-according to Wandel, it did not change significantly for the general Ottoman Armenian population after the empire entered World War I by attacking Russia and began to deport and massacre Armenians. In any case, as Wandel also pointed out, the question of "loyalty" had little, if anything, to do with the persecution of the Armenians, since, as his 4 September report emphasizes, the persecutions at this point took place with no regard to whether the targeted Armenians could even theoretically be construed to constitute any real threat to the Ottoman Empire. After having stated that the slaughter of the Armenians continued "with great intensity," in spite of promises to the contrary that he and other diplomats had personally received from the Young Turk government, Wandel mentions that even the Armenian Catholics, who, he states, never had any political aspirations, and the Gregorian Armenians, "who have distanced themselves from nationalist ideas to such an extent that they have given up their mother tongue and adopted the Turkish language as their own," were still subjected to "the most stubborn persecution."

\section{The Economy of Genocide: The "Confiscations" of Armenian Property}

Another central aspect of the genocide, the "legal" background for the deportation of the Armenians and the confiscation of Armenian assets by the Young Turk government, was also analyzed by Wandel. On 27 May 1915, only three days after the Entente had threatened to hold Turkish civilians and military personnel responsible for "crimes against humanity," the CUP rushed the passing of a law that basically gave the authorities carte blanche to deport any person they wanted. ${ }^{112}$ The authorities, Wandel emphasized, had only to "sense" treason to justify the deportation of whole cities. ${ }^{113}$ On 26 September 1915, a second "temporary law" was passed, without the consent of the temporarily suspended parliamentary chambers, concerning the confiscation of (Armenian) assets. It is described by Wandel as follows:

The new temporary law prescribes that the possessions of the deported Armenians are to be confiscated by the public administration. According to the law ... it will be possible to confiscate the land belonging to all of the deported Armenians, as well as Armenian churches and schools. It is clear that the forced sale of the property, head over heels and under the current conditions, will not come close to covering the actual value of the property. The liquidation commission mentioned in the law can act completely arbitrarily. It has been given authority to annul any claims of the deported without consulting said persons, and to hand over property to other claimants without giving the deported any right or possibility to set aside such a decision. Any surplus generated by the liquidation of the possessions of the deported will, after deduction of expenses, be deposited in the ministry of finance, without any mention of when it is supposed to be paid back to the owners. Considering that the law of 27 May 1915 has laid the legal foundation for the great deportations of the Armenians and for the connected persecutions, it is easy to imagine the far-reaching consequences of an arbitrary execution of the provisions of the new law, which practically could lead to complete ruin for the Armenians of Asia Minor. ${ }^{114}$ 
The Austrian military attaché to the Ottoman Empire, Joseph Pomiankowski, simply stated that the law was a farce. ${ }^{115}$ Its aim was, in reality, to "legalize" and systematize the widespread profiteering from the genocide by the state, officials, the army, Muslim refugees, and local populations. In several reports Wandel mentions that the only real high-level Turkish voice of protest against the plundering and persecution of the Armenians came from Senator Ahmed Riza. ${ }^{116}$ This is perhaps somewhat surprising, since the European-educated senator, formerly a leading Young Turk ideologue, president of the Ottoman Chamber of Deputies, chairman of the CUP, and still a convinced and idealistic Turkist, had earlier displayed no particular sympathy toward the Christian minorities of the empire. ${ }^{117}$ In fact, he was early on believed to belong to the radical wing of the Young Turks, as can be discerned from the statement of a person present at a lecture given by Riza in London in 1904:

I am not sorry that the gentleman has spoken, because it shows us how impossible it is to expect any reforms in Turkey from the Young Turk party. They are only thinking of themselves. The liberties of the Christians would be just as unsafe under a Sultan with the sentiments of the gentleman [Riza] who has just sat down, as under the present Sultan. ${ }^{118}$

But Riza definitely felt that, during the Great War, the Young Turk government went much too far in carrying out its oppressive policies against minorities such as the Armenians, a minority that, in large part, lived in provinces where Christians had never experienced justice or security, as he stated during a parliamentary debate in 1916. ${ }^{119}$ Riza's scolding criticism of Young Turk policies could even be seen as a logical, if unusually principled, extension of his democratic beliefs, as well as of his earlier, equally scolding criticism of Western imperialism and racism. ${ }^{120} \mathrm{He}$ also tried constantly to convince his colleagues in the Ottoman senate that the laws "legalizing" these Young Turk policies were unconstitutional and unjust. ${ }^{121}$ Although Ahmed Riza's protests were obviously in vain, and although he was frequently harrassed in Parliament by his colleagues, he did not give up on a subject that was, to him, a matter of conscience and principle.

As late as November 1917, Riza and the three other members of his small Young Turk parliamentary faction (Orkhan Bey, Mahmoud Pasha, and Damad Ferid Pasha) insisted on debating in the Ottoman parliament the unlawful confiscation of what were euphemistically called "abandoned properties" and the connected persecutions of Armenians, Greeks, and Arabs. This was highly unusual during the reign of the Young Turk dictatorship, since no real debate was allowed either in the governmentcontrolled press or in Parliament; when a case was brought before the parliament, it had already been decided upon by the CUP. But Riza was occasionally allowed to speak out without being disciplined or punished, and he even made sure that the criticism he raised in the Senate was, to some extent, printed in the official parliamentary record. That record was not accessible to the public, but at least some of the legations managed to get hold of it. ${ }^{122}$ The reasons that Riza was allowed to speak out were that he, a man of integrity and some influence as one of the founders of the CUP, was still highly esteemed among parts of the general population and the elite, and also that, because he lacked a proper power base, he was regarded as relatively harmless, or even useful, by the Young Turks, as they could point to his presence in the Senate to claim that, since there was an opposition, the empire was ruled in a truly parliamentary fashion. ${ }^{123}$

During the Senate meeting of 29 November 1917, the government proposed a law that would grant an official commission two million piastres to administer 
"the preservation of the abandoned properties." This seemingly innocent proposition would, if passed, be a de facto legalization of the Temporary Law of Expropriation and Confiscation of 1915, which allowed the government to "confiscate"-that is, stealArmenian cash and property and to resell the property for profit. In the preceding two years the government had not dared to introduce that law to the parliamentary chambers, and the introduction of the appropriation law was thus an obvious attempt to obtain an indirect parliamentary blessing for an unconstitutional law. Orkhan Bey started the debate by saying exactly this: that, as the provisional or temporary law regarding the "abandoned properties" had not yet been introduced to and approved by the Senate, granting the requested two million piastres would give the appearance that the Senate was approving a law it had not been given the opportunity to properly debate and approve. The Senate president, without directly commenting on Orkhan Bey's assertions, assured him that this would not be the case.

Then Riza spoke, echoing his protests in Parliament against the "temporary law" two years earlier, in the fall of $1915 .{ }^{124}$ Among other things, he pointed to the fact that the very term "abandoned properties" was ridiculous:

We take responsibility by accepting an expression. In my opinion the expression "abandoned properties" means property that has been abandoned, left behind. But no one has left behind their property of their own free will. We must find an appropriate expression and say straight out, "Law for the Preservation of Possessions of Armenians, Greeks, and Arabs, who out of Political Necessity have been Removed from their Homes." The expression "abandoned properties" is not accurate, and the Senate should not accept such an inaccurate expression. In reality the population has been violently driven from their homes and been abducted by force, and their property has been left behind. This line of action is also unconstitutional, because the constitution protects the inviolability of property. I will go further and say that if the rights of property do not exist in a country ..., no government exists either .... The government does claim that it has had the right to such action. Since I have yet to examine the matter in its entirety, I cannot for the moment give a definite statement thereof. The government publishes brochures with its viewpoints. Let us assume that every word in these brochures is absolutely true. Some Armenians and Greeks may very well, as the government says, have been traitors. Those you find among the Turks and the Kurds, as well as among the Armenians. But the law establishes punishment for the traitors, the criminals. You execute them, shoot them; but you never deport their families or rob their fortune. This is an outright reign of terror. ${ }^{125}$

The Senate president was of the opinion that all of this could be discussed only when the law in question, the September 1915 law, was introduced to the Senate. But, as Riza stated once again, that law had not been introduced, and there was no sign that this would actually happen. The Senate president also remarked that the Senate had earlier approved the expression "abandoned properties," and he thought it strange not to accept it this year. Riza answered that he himself had not accepted it, nor would he. He once again demanded the introduction of the confiscation law, not the "auxiliary" appropriation law: "We have to know that the properties are not lost, that they remain to be given back to their rightful owners, and that these are not all dead." The president said that the confiscation law had been introduced to the Chamber of Deputies, but that it had not been read because of that chamber's workload, and that the Senate therefore could not blame the government. After further protests from Riza's group, who knew this to be a phony explanation, the law was passed. Thus, the Senate ended up indirectly sanctioning the bill that Riza and his small group had fought so vigorously against, the bill that indirectly "legalized" what was, 
according to Jesse B. Jackson, American consul to Aleppo, "a gigantic plundering scheme as well as a final blow to extinguish the [Armenian] race."126

\section{Conclusion}

Space permits only an introduction to some of the most important subjects covered by Carl Ellis Wandel in relation to the Armenian Genocide. For instance, his often long and analytical reports also deals extensively with subjects such as the question of "German complicity," the dynamics and relationships within the Young Turk leadership, and the official Young Turk campaign of denial and falsification of their crimes. But the sample of documents analyzed and contextualized above should leave the impression that even an unknown diplomat from a small country has something to offer when it comes to explaining important aspects of one of the largest exterminatory projects of the twentieth century. For, as Wandel convincingly argued, this was the nature of the Armenian Genocide: it was an extremely cruel, pragmatic, and opportunistic political and economical project, fueled by a highly xenophobic, nationalist (proto-)ideology, all in the context of war and of a "grand scheme" of radical modernization by Turkification. Contemporary official justifications of the persecutions-"military necessity," Armenian "disloyalty" or "provocation"-were dismissed as exaggerated, fabricated, or simply irrelevant. Wandel concurred with most other contemporary and later observers that the Ottoman Armenians did not bring their fate upon themselves.

In other words, pragmatic considerations, combined with a downward spiral of more and more radicalized rhetoric and actions, as well as the opportunity created by a world war, were, for Wandel, essential in understanding why the anti-Armenian policies were intended and carried out as complete destruction and not, say, ethnic cleansing or continued oppression. To him, it was what we today would call a twisted road to the Armenian Genocide, which is probably why he did not attempt to estimate the exact time of the conception of a Young Turk plan of actual genocide. This does not mean that Wandel was taking sides, in 1915 and 1916, in a debate of "intentionalists" versus "functionalists," as such a debate obviously did not exist at the time. If it had, it would most likely not have seemed to be of even academic interest to an eyewitness, in the face of the ongoing slaughter. Wandel simply reported on what he saw, heard, and read, as the often seemingly chaotic events progressed, and he came to conclusions about important aspects of the nature of the Armenian Genocide that are quite similar to conclusions many (but not all) contemporary observers, as well as many present-day scholars (myself included), have come to on the basis of available evidence.

\section{Notes}

1. On the number of Armenian deaths, see two recent works covering these massacres: Arman J. Kirakossian, ed., The Armenian Massacres, 1894-1896: U.S. Media Testimony (Detroit, MI: Wayne State University Press, 2004), 29, states that "more than 300,000 Armenians were massacred," while Donald Bloxham, The Great Game of Genocide: Imperialism, Nationalism, and the Destruction of the Ottoman Armenians (Oxford University Press, 2005), 51, states that the massacres "took 80-100,000 lives directly and tens of thousands indirectly in 1894-6."

2. G. Godet, Forfølgelserne i Armenien (Copenhagen: J. Frimodts Forlag, 1897), 41, 52-53.

3. See, e.g., Åge Meyer Benedictsen, Armenien-Et Folks Liv og Kamp gennem to Aartusinder (Copenhagen: De Danske Armeniervenner, 1925), 210-12. 
4. Georg Brandes, Udvalgte Skrifter, vol. 8., Journalistik og Debat, ed. Sven Møller Kristensen (1900; reprint, Copenhagen: Tiderne skifter 1987), 133.

5. Benedictsen got the inspiration to found DA after visiting projects established by Johannes Lepsius's Deutsche Orient Mission in Van, Khoi, and Urfa: Åge Meyer Benedictsen, Age Meyer Benedictsen-De Undertrykte Nationers Tolk. En Mindebog, vol. 1, ed. Katri Meyer Benedictsen (Copenhagen: Nyt Nordisk Forlag/Arnold Busck, 1934), 125.

6. H.V. Styhr, Armenien og Armenierne, special issue of Vort Land (1897), 15.

7. For an English-language analysis of the work of this commission, including the role of Jeppe from her post-war base in Aleppo, see Vahram L. Shemmassian, "The League of Nations and the Reclamation of the Armenian Genocide Survivors," in Looking Backward, Moving Forward: Confronting the Armenian Genocide, ed. Richard G. Hovannisian (New Brunswick, NJ: Transaction Publishers, 2003), 81-112.

8. Svend Cedergreen Bech, Hos et Folk Uden Land (Copenhagen: GEC Gad, 1982); Ingeborg Marie Sick, Pigen Fra Danmark, 4th ed. (Copenhagen: Gyldendal, 1945); Eva Lous, "Karen Jeppe: Denmark's First Peace Philosopher," The Danish Peace Academy, 2003, http:// www.fredsakademiet.dk/library/ukjeppe.htm (accessed 23 December 2005); Matthias Bjørnlund, "Karen Jeppe," Folkedrab.dk, 2004, http://www.folkedrab.dk/folkedrabene/ armenien/fokus/karenjeppe/(accessed 23 December 2005); Ephraim K. Jernazian, Judgment unto Truth: Witnessing the Armenian Genocide (New Brunswick, NJ: Transaction Publishers, 1990), 65-67, 156; Maria Jacobsen, Maria Jacobsen's Diary 1907-1919, Kharput_Turkey (Antelias, Lebanon: Armenian Catholicosate, 1979); Maria Jacobsen, Diaries of a Danish Missionary-Harpoot, 1907-1919, ed. Ara Sarafian (Princeton, NJ: Gomidas Institute Books, 2001); Amalie Lange, Et Blad af Armeniens Historie-KMA 1910-1920 (Copenhagen: KMA, 1920).

9. Kraks Blaa Bog (Copenhagen: Kraks Legat, 1931), 1014.

10. See, e.g., Scavenius's account of the desired Danish foreign policy during World War I, in the Archives of the Foreign Ministry, Danish National Archives (UM), Gr. 5. D. 28, "Diskussionen ved det Fortrolige Møde i Rigsdagen 3. December 1915." At a confidential meeting in the Danish Parliament, Scavenius strongly (and largely unsuccesfully) urged politicians from all parties to pressure the news media to seize what he called "excesses," that is, negative or critical coverage of Germany. See also Bo Lidegaard, Overleveren, 1914-1945 (Copenhagen: Gyldendal, 2003), 24-37.

11. “14. Møde, fredag d. 29/12 1916," in Ministermødeprotokol 1916-18, Kirkeminister Th. Povlsens referater, ed. Tage Kaarsted (Århus: Universitetsforlaget i Århus, 1973), 40.

12. UM, Gr. 139. N. 1., "Armenien," coded telegram from the Danish legation in Stockholm to Scavenius, 25 April 1918; UM, Gr. 139. N. 1., "Armenien," note from the Danish Foreign Ministry to Krieger, private secretary to Christian X, the Danish king, 27 April 1918.

13. Rouben Paul Adalian, "American Diplomatic Correspondence in the Age of Mass Murder: The Armenian Genocide in the US Archives," in America and the Armenian Genocide of 1915, ed. Jay Winter, 146-84 (Cambridge: Cambridge University Press, 2003), 147-48.

14. UM, Gr. 139, Afd. D. 1., "Tyrkiet-Indre Forhold," pakke 1, til 31. Dec. 1916, nr. CXXIX, 26 September 1915. Unless otherwise indicated, all translations are my own.

15. Wolfgang Gust, ed., Der Völkermord an den Armeniern 1915/16: Dokumente aus dem Politischen Archiv des deutschen Auswärtigen Amts (Springe: zu Klampen, 2005), 173.

16. UM, Gr. 139, Afd. N. 1, “Armenien,” nr. LXXXXVIII, 27 April 1916.

17. UM, Gr. 139, Afd. N. 2., "Tyrkiet: Behandling af Grækere paa tyrkisk Omraade," nr. XVI, 24 January 1917.

18. On Morgenthau's meetings with Wandel, see Henry Morgenthau, United States Diplomacy on the Bosporus: The Diaries of Ambassador Henry Morgenthau, 1913-1916, comp. and introd. Ara Sarafian (Princeton, NJ: Gomidas Institute, 2004).

19. See, e.g., UM, Gr. 139, Afd. D. 1., "Tyrkiet-Indre Forhold," Pakke 2, Jan. 1917-1. Jan. 1919, nr. IV, 6 January 1917, in which Wandel mentions an informant who is a member of the Ottoman senate; UM, Gr. 139, Afd. D. 1., "Tyrkiet-Indre Forhold," Pakke 2, Jan. 1917-1. Jan. 1919, nr. CXVII, 28 July 1917, in which Wandel mentions as an 
informant who is a "high-ranking Freemason who believes he has Talât Pasha's confidence."

20. On information on the genocide in Harput and Mezreh recieved by Wandel from letters written by Danish missionaries, and delivered personally by a German physician, see UM, Gr. 139, N. 1., "Armenien" [no number], 10 April 1917.

21. Wolfgang Gust, "Einleitung und Leitfaden," in Der Völkermord an den Armeniern 1915 / 16: Dokumente aus dem Politischen Archiv des deutschen Auswärtigen Amts, ed. Wolfgang Gust, 17-109 (Springe: zu Klampen, 2005), 19.

22. Gust, Der Völkermord, 186. See also Vahakn N. Dadrian, German Responsibility in the Armenian Genocide: A Review of the Historical Evidence of German Complicity (Watertown, MA: Blue Crane Books, 1997), 22.

23. Ara Sarafian, "Editor's Introduction," Ambassador Morgenthau's Story, by Henry Morgenthau, ed. Ara Sarafian (1918; repr., Ann Arbor, MI: Gomidas Institute, 2000), $\mathrm{x}, \mathrm{n} .9$.

24. Quoted in Bertil Bengtsson, Svärdets År-Om Folkmordet på de Kristna $i$ Turkiet 1894-1922 (Södertälje: Syrianska Riksförbundet, 2004), 118.

25. See, e.g., Stephan H. Astourian, "Modern Turkish Identity and the Armenian Genocide: From Prejudice to Racist Nationalism," in Remembrance and Denial: The Case of the Armenian Genocide, ed. Richard G. Hovannisian, 23-49 (Detroit, MI: Wayne State University Press, 1998), 40-41; Martin Niepage, Rædslerne i Aleppo. Sete af et Tysk Øjenvidne (London, 1917), 18.

26. See discussion in Ronald Grigor Suny, "The Holocaust before the Holocaust: Reflections on the Armenian Genocide," in Der Völkermord an der Armeniern und die Shoah/The Armenian Genocide and the Shoah, ed. Hans-Lukas Kieser and Dominik J. Schaller, 83-100 (Zurich: Kronos Verlag, 2002).

27. For a recent example of a convincing, predominantly "structuralist" interpretation, see Bloxham, The Great Game, 66-68. It must be noted that few scholars of the Armenian genocide fall easily into neat "structuralist" and "intentionalist" categories. For instance, no "structuralist" scholar has, to my knowledge, denied the importance of, say, pre-war Armenian massacres and Young Turk radicalism as determinants of the genocide. Likewise, a known proponent of a predominantly "intentionalist" interpretation of the genocide, Vahakn N. Dadrian, in his review essay, "Comments on Robert Melson's Revolution and Genocide," Holocaust and Genocide Studies 8 (1994): 410-15, 414-15, talks cautiously of "situational determinants" and of the "genocidal thrust" as "more of an outgrowth of interactive processes, in the course of which the conflict escalates, opportunities for radical solutions emerge, and the exercise of power through the application of lethal force becomes affordable." For a convincing argument that genocide and other crimes against humanity usually evolve from some amount of contingency rather than from a blueprint, see Michael Mann, The Dark Side of Democracy: Explaining Ethnic Cleansing (Cambridge: Cambridge University Press, 2005).

28. See especially Vahakn N. Dadrian, "The Secret Young Turk-Ittihadist Conference and the Decision for the World War I Genocide of the Armenians," Holocaust and Genocide Studies 7 (1993): 178-83. For a recent example, see Hayk Ghazarian, The Genocide of the Armenian People in the Ottoman Empire (Yerevan: Tigran Mets, 2005), 39.

29. Taner Akçam, From Empire to Republic: Turkish Nationalism and the Armenian Genocide (London: Zed Books, 2004), 164-68; Bloxham, The Great Game, 87-88; Hilmar Kaiser, "“A Scene from the Inferno': The Armenians of Erzerum and the Genocide, 1915-1916," in Der Völkermord an der Armeniern und die Shoah/The Armenian Genocide and the Shoah, ed. Hans-Lukas Kieser and Dominik J. Schaller, 129-86 (Zurich: Kronos Verlag, 2002), 172.

30. See, e.g., Robert Gellately and Ben Kiernan, eds., The Specter of Genocide: Mass Murder in Historical Perspective (Cambridge: Cambridge University Press 2003), 10-11.

31. Vahakn N. Dadrian, The History of the Armenian Genocide: Ethnic Conflict from the Balkans to Anatolia to the Caucasus, 2nd ed. (Oxford: Berghahn Books, 1997), 5. See also 
George Horton, The Blight of Asia: An Account of the Systematic Extermination of Christian Populations by Mohammedans and of the Culpability of Certain Great Powers; with the True Story of the Burning of Smyrna (1926; London: Sterndale Classics, 2003), 15ff; Akçam, From Empire to Republic, 75.

32. Progrès de Salonique, 22 July 1910, quoted in Horton, The Blight of Asia, 20. See also M. Sükrü Hanioglu, Preparation for a Revolution: The Young Turks, 1902-1908 (Oxford: Oxford University Press, 2001), 304.

33. Dimitri Pentzopoulos, The Balkan Exchange of Minorities and Its Impact on Greece (1962; London: Hurst \& Co. 2002), 53.

34. Johannes Østrup, Erindringer (Copenhagen: H. Hirschprungs Forlag, 1937), 118; see also $112,117,132-35$. For Østrup's views on Atatürk, see ibid., 212-26.

35. On the view of Sultan Abdul Hamid II of Armenians as "womanly," see Ronald Grigor Suny, "Religion, Ethnicity, and Nationalism: Armenians, Turks, and the End of the Ottoman Empire," in In God's Name: Genocide and Religion in the Twentieth Century, ed. Omer Bartov and Phyllis Mack, 23-61 (New York: Berghahn Books, 2001), 42.

36. Johannes Østrup, Skiftende Horizonter-Skildringer og Iagttagelser fra et Ridt Gjennem Ørkenen og Lilleasien (Copenhagen: Gyldendal, 1894), 243. See also Astourian, "Modern Turkish Identity," 28-31; Wolfgang Gust, "Die Verdrängung des Völkermords an den Armeniern-ein Signal für die Shoah," in Der Völkermord an der Armeniern und die Shoah / The Armenian Genocide and the Shoah, ed. Hans-Lukas Kieser and Dominik J. Schaller, 463-80 (Zurich: Kronos Verlag, 2002), 466-69; Hilmar Kaiser, Imperialism, Racism, and Development Theories: The Construction of a Dominant Paradigm on Ottoman Armenians (Ann Arbor, MI: Gomidas Institute, 1998). Leon Arpee, A History of Armenian Christianity from the Beginning to Our Own Time (New York: Armenian Missionary Association of America, 1946), 309, gives an early analysis of the background for Western Armenophobia and, by implication, for Western genocide denial, and how it echoes what Arpee calls "the Turkish need to defame the victims of his own barbarity": "Sometimes it has a commercialistic origin, as when some foreign business adventurer goes East in the hope of making big money, runs up against Armenian competition, and vents his disappointed ire blackening the character of a whole people. Some Armenophobia, too, has had railroad, mining, oil or other Turkish concession in view, or perhaps another Turkish loan on terms advantageous to the lenders, or the readjustment of policies of state in certain European cabinets, or the protection of vested interests as in the case of certain American educators. It may sometimes even have a semi-religious motive behind it, as when a missionary lets his zeal get the better of him in painting the darker side of the picture with the purpose of impressing the home constituency with the undeniable moral and spiritual need." It must be noted that many contemporary Western observers expressed equally deep resentment of the Muslim populations of the Ottoman Empire. Bloxham, The Great Game, 117, states that "almost everyone posted to the Ottoman Empire expressed disdain for one or other of the ethnic groups with which they came into contact."

37. O. Stiehl, Unsere Feinde-96 Charakterköpfe aus Deutschen Kriegsgefangenlagern (Stuttgart: Verlag Julius Hofmann, 1917), 27. "Typical" portraits of the Armenian "racial type" are shown on pages $81-82$.

38. Bloxham, The Great Game, 8-9; Akçam, From Empire to Republic, 78-87. On the concept of "middlemen"-minorities envied and hated for their (perceived) economic dominance-see Stacey Gibson, "The Role of Structure and Institutions in the Genocide of the Rwandan Tutsi and the Armenians of the Ottoman Empire," Journal of Genocide Research 5 (2003): 503-22, especially 503-7.

39. Most importantly in Dadrian, History; Melson, Revolution and Genocide. See also discussion between Ronald Grigor Suny, "Empire and Nations: Armenians, Turks, and the End of the Ottoman Empire," Armenian Forum 1 (1998): 17-51, and 
Vahakn N. Dadrian, "The Armenian Genocide and the Pitfalls of a 'Balanced' Analysis," Armenian Forum 1 (1998): 73-130.

40. See, e.g., Hans-Lukas Kieser and Dominik J. Schaller, "Einleitung. ...," in Der Völkermord an der Armeniern und die Shoah / The Armenian Genocide and the Shoah, ed. Hans-Lukas Kieser and Dominik J. Schaller, 17-21 (Zurich: Kronos Verlag, 2002).

41. Akçam, From Empire to Republic, 63, 92.

42. For a very positive contemporary assessment of the Young Turk revolution, see Angus Hamilton, Problems of the Middle East (London: Eveleigh Nash, 1909), 1-61.

43. Quoted in Inger Marie Okkenhauge, "Bodil Biørn and the Armenian People," unpublished manuscript (2005), 8.

44. Elise Bockelund, En Tjenergerning blandt Martyrfolkene. Kvindelige Missions Arbejdere 1900-1930 (Elsinore: KMA, 1932), 24.

45. UM, Gr. 139, Afd. D. 1, “Tyrkiet-Indre Forhold,” Pakke 1, til 31 dec. 1916, nr. II, 24 July 1914. See also Donald Bloxham, "Determinants of the Armenian Genocide," in Looking Backward, Moving Forward: Confronting the Armenian Genocide, ed. Richard G. Hovannisian, 23-50 (New Brunswick, NJ: Transaction Publishers, 2003), 28; Anahide Ter Minassian, "Van 1915," in Armenian Van/Vaspurakan, ed. Richard G. Hovannisian, 209-44 (Costa Mesa, CA: Mazda Publishers, 2000), 211.

46. UM, Gr. 139, Afd. D. 1., "Forholdene i Tyrkiet," nr. XIV, Rom, 1 April 1911.

47. Akçam, From Empire to Republic, 127-28.

48. UM, Gr. 139, Afd. D. 1., "Forholdene i Tyrkiet," nr. XIV, Rom, 1 April 1911.

49. Akaby Nassibian, Britain and the Armenian Question 1915-1923 (London: Croom Helm, 1984), 13.

50. See, e.g., Akcam, From Empire to Republic, 130-31.

51. UM, Gr. 139, Afd. D. 1., "Tyrkiet-Indre Forhold," Pakke 1, til 31 dec. 1916, nr. CXXV, 23 September 1915. The view that Turkist ideology before the Great War was in fact radically exclusive is shared by even the well-known deniers of the Armenian Genocide, Stanford J. Shaw and Ezel Kural Shaw, History of the Ottoman Empire and Modern Turkey, vol. 2, Reform, Revolution, and Republic: The Rise of Modern Turkey, 1808-1975 (Cambridge: Cambridge University Press, 1977), 262: "Of course Turkish nationalism, if brought to its logical conclusion, contradicted both Ottomanism and Islamism. If the empire was made into a Turkish national state, there would be no room not only for most of the non-Muslims but also for the non-Turkish Muslims who supported the empire because of their position as Muslims."

52. See, e.g., Hugh Poulton, Top Hat, Grey Wolf and Crescent: Turkish Nationalism and the Turkish Republic (London: Hurst \& Co., 1997), 80-81; Christopher J. Walker, Armenia: The Survival of a Nation (New York: St. Martin's Press, 1981), 188-95; Akçam, From Empire to Republic, 65.

53. Feroz Ahmad, The Young Turks: The Committee of Union and Progress in Turkish Politics (Oxford: Oxford University Press, 1969), 163.

54. See, e.g., Erik J. Zürcher, Turkey: A Modern History (London: I.B. Tauris, 1997), 132-37.

55. UM, Gr. 139, Afd. D. 1., "Tyrkiet-Indre Forhold," Pakke 1, til 31 dec. 1916, nr. CLX, 22 September 1915.

56. Ugur Ü. Üngör, "A Reign of Terror: CUP Rule in Diyarbekir Province, 1913-1918" (master's thesis, University of Amsterdam, 2005), 6.

57. Suny, "The Holocaust before the Holocaust," especially 94-98; Bloxham, "Determinants of the Armenian Genocide," 24-34; Üngör, "Reign of Terror," 13-15, $17 \mathrm{ff}$.

58. See, e.g., Üngör, ibid., 20-21; Akçam, From Empire to Republic, 138-39. On the direct connection between Young Turk linguistic policies and the subsequent genocide, see Kaiser, "A Scene from the Inferno," 28.

59. Akçam, From Empire to Republic, x. On the ongoing marginalization of non-Turkish citizens in modern Turkey, see ibid., 5.

60. UM, Gr. 139, Afd. D. 1., "Politiske Begivenheder i Tyrkiet i 1914," Gesandtskabet i Konstantinopel, 26 January 1915, 2. 
61. UM, Gr. 139, Afd. D. 1., “Tyrkiet-Indre Forhold,” Pakke 1, til 31 dec. 1916, nr. II, 24 July 1914. Compare this with Morgenthau's report on 26 May 1915 (i.e., at a more radicalized and disillusioned stage for the Young Turks and the Armenians, respectively), in Ara Sarafian, comp., The United States Official Records on the Armenian Genocide, 1915-1917 (Princeton, NJ: Gomidas Institute, 2004), 32: "The sharp oscillations in the treatment to which [the Ottoman Armenian community] has been subjected since the Turkish

Revolution have taken a markedly unfavorable turn by reason of the War. The fact is that the present Ottoman Government no longer count on the Armenians as loyal to them. The hardships and oppression the Armenians have suffered in recent years, compared with the most favorable treatment received in Russia has caused them not unnaturally to contrast their lot with that of their co-religionists there. The first glamour of the constitutional era here, soon disappeared, while the recollection of the Adana Massacre in 1909 is still fresh in their minds. It is therefore not unlikely to suppose that the great majority of the Armenians in common with all non-Moslem communities, as well as many Turks ardently hope for a change in Government. Between the wish and the ability to realize this there lies, however, a wide gulf. Apart from the mountainous region in Eastern Armenia, and the Zeitoun district, North of Alexandrette, the Armenians no more than other dissatisfied communities, possess the means or the determination to give expression to their wishes."

62. UM, Gr. 139, Afd. D. 1., “Tyrkiet-Indre Forhold,” Pakke 1, til 31 dec. 1916, nr. II, 24 July 1914.

63. See also Üngör, "Reign of Terror," 20-21; Zürcher, Turkey, 133-35.

64. UM, Gr. 139, Afd. D. 1., "Tyrkiet-Indre Forhold," Pakke 1, til 31 dec. 1916, nr. CLXXXVIII, 6 December 1915. See also Henry Morgenthau, Ambassador

Morgenthau's Story (1918; reprint, Detroit, MI: Wayne State University Press, 2003), 19697.

65. UM, Gr. 139, Afd. D. 1., "Politiske Begivenheder i Tyrkiet i 1914," Gesandtskabet i Konstantinopel, 26 January 1915, 19.

66. UM, Gr. 139, D. 1., "Tyrkiet-Indre Forhold," Pakke 1, til 31 dec. 1916, nr. LXXI, 7 June 1915. For mention of Ahmed Bey as a Turkist ideologue, see Astourian, "Modern Turkish Identity," 45, n. 41; Zürcher, Turkey, 133.

67. Hans-Lukas Kieser, "Dr Mehmed Reshid (1873-1919): A Political Doctor," in Der Völkermord an der Armeniern und die Shoah/The Armenian Genocide and the Shoah, ed. Hans-Lukas Kieser and Dominik J. Schaller, 245-80 (Zurich: Kronos Verlag, 2002), 257.

68. UM, Gr. 139, Afd. D. 1., "Tyrkiet-Indre Forhold," Pakke 1, til 31 dec. 1916, nr. CLVII, 23 November 1916. See also Üngör, "Reign of Terror," 16. For a photograph of a group of militarized "boy scouts," here called "Türkische Wehrkraftjungen" (literally, "Turkish defense-force boys"), see Franz Carl Endres, Die Türkei (München: Delphin-Verlag, 1916), 33.

69. UM, Gr. 139, Afd. D. 1., "Tyrkiet-Indre Forhold," Pakke 1, til 31 dec. 1916, nr. CLVII, 23 November 1916. On Adil Bey as a moderate, that is, opposed to the Armenian genocide, see Gust, Der Völkermord an den Armeniern, 315.

70. UM, 4. F. 2, “Tyrkiet: Gesandtskabet her," Oprettelse 1916, Djevad Bey, 22/2-15/12 1916. Extrakt-Afskrift af Privatbrev nr. 24 fra Ministerresident C. E. Wandel til Udenrigsminister Scavenius, Konstantinopel, 5 November 1915.

71. UM, Gr. 139, Afd. D. 1., "Tyrkiet-Indre Forhold," Pakke 1, til 31 dec. 1916, nr. XCVII, 14 August 1915. One likely reason for the resistance to Western-style modernization among parts of the Ottoman Muslim establishment that the Young Turks encountered from the beginning was that modernization was seen to benefit Christian minorities and foreigners only: Kaiser, "A Scene from the Inferno," 36-37. This is one of the ways that modernization by Turkification could also be seen as an attempt to secure the loyalty and cooperation of the "Old Turks."

72. Suny, "The Holocaust before the Holocaust," 91. 
73. UM, Gr. 139, Afd. D. 1., “Tyrkiet-Indre Forhold," Pakke 2, Jan. 1917-1. Jan. 1919, nr. LXXII, 13 August 1918. See also Morgenthau, Ambassador Morgenthau's Story (2003 ed.), 238.

74. Akçam, From Empire to Republic, 56, 92-100. See also Bernard Lewis, The Emergence of Modern Turkey (London: Oxford University Press, 1961), 355-56.

75. UM, Gr. 139, Afd. D. 1., "Tyrkiet-Indre Forhold," Pakke 1, til 31 dec. 1916, nr. CLVII, 23 November 1916. See also Akçam, From Empire to Republic, 117.

76. UM, Gr. 139, Afd. N. 1., "Armenien," nr. LIV, 10 March 1916.

77. Morgenthau, Ambassador Morgenthau's Story (2003 ed.), 222-23; Akçam, From Empire to Republic, 147. According to Alfred Van der Zee, some 70,000-80,000

Ionian Greeks had been expelled already before June 1914: UM, Gr. 5. L. 15., “Grækenland-Tyrkiet: Politiske Forhold," Pakke 1, Juni 1914-31/12 1945, nr. 41, 27 June 1914.

78. Akçam, From Empire to Republic, 144-49.

79. UM, Gr. 355, "Gesandtskabet i Konstantinopel-Noter og indberetninger om den politiske Udvikling 1914-1922. Rapporter fra Smyrna Nov. 1914-Marts 1916,” nr. 184, 19 June 1914; nr. 202, 25 June 1914. See also Horton, The Blight of Asia, 28-34.

80. UM, Gr. 5. L. 15., "Grækenland-Tyrkiet: Politiske Forhold,” Pakke 1, Juni 1914-31/12 1945, nr. 31, 23 June 1914.

81. UM, Gr. 139, Afd. D. 1., "Politiske Begivenheder i Tyrkiet i 1914," indsendt af Gesandtskabet i Konstantinopel, 26 January 1915, 17. For the estimated number of bashibozuks, see UM, Gr. 5. L. 15., "Grækenland-Tyrkiet: Politiske Forhold," Pakke 1, Juni 1914-31/12 1945, nr. 31, 23 June 1914.

82. UM, Gr. 5. L. 15., "Grækenland-Tyrkiet: Politiske Forhold," Pakke 1, Juni 1914-31/12 1945, nr. 31, 23 June 1914.

83. UM, Gr. 139, Afd. D. 1., "Politiske Begivenheder i Tyrkiet i 1914," indsendt af Gesandtskabet i Konstantinopel, 26 January 1915, 17; UM, Gr. 5. L. 15., "GrækenlandTyrkiet: Politiske Forhold," Pakke 1, Juni 1914-31/12 1945, nr. 26, 19 June 1914; UM, Gr. 5. L. 15., "Grækenland-Tyrkiet: Politiske Forhold," Pakke 1, Juni 1914-31/12 1945, nr. 28, 20 June 1914. See also Pentzopoulos, The Balkan Exchange, 53-54.

84. UM, Gr. 5. L. 15., "Grækenland-Tyrkiet: Politiske Forhold," Pakke 1, Juni 1914-31/12 1945, nr. 26, 19 June 1914.

85. Akçam, From Empire to Republic, 146-47; UM, Gr. 139, Afd. N. 2., "Tyrkiet: Behandling af Grækere paa tyrkisk Omraade" [ca. 1917-1922], nr. X, 14 January 1917.

86. Akcam, From Empire to Republic, 148. A conceptual note: I would characterize the Young Turk persecutions of Ottoman Greeks in 1914-1918 as genocide, even though the extent and, perhaps, also the intent of the killings differ from the extermination of the Armenians, as well as the Nestorians and Assyrians, of the Ottoman Empire. Mark Levene, in "Creating a Modern 'Zone of Genocide': The Impact of Nation- and State-Formation on Eastern Anatolia, 1878-1923," Holocaust and Genocide Studies 12 (1998): 393-433, makes a plausible argument that even though the Armenian Genocide, like the Holocaust and the Rwandan genocide, was one of the rare instances of what he calls "total genocide," other aspects of the Young Turk campaign of "homogenizing" Anatolia can be characterized as "partial genocide." On "total" and "partial" genocide, see also Robert F. Melson, Revolution and Genocide: On the Origins of the Armenian Genocide and the Holocaust (Chicago: University of Chicago Press, 1992).

87. UM, Gr. 5. L. 15., "Grækenland-Tyrkiet: Politiske Forhold," Pakke 1, Juni 1914-31/12 1945, nr. 41, 27 June 1914.

88. Ibid.

89. Morgenthau, Ambassador Morgenthau's Story (2003 ed.), 232.

90. Akçam, From Empire to Republic, 149; Morgenthau, Ambassador Morgenthau's Story (2003 ed.), 34-36.

91. Kieser, "Dr Mehmed Reshid." Sükrü Bey, the director of the Ministry of the Interior's all-important Directorate for the Settlement of Tribes and Immigrants, is another example 
of a "modern" (i.e., biological and eliminatory) racist Young Turk: Gust, Der Völkermord an den Armeniern, 421.

92. UM, Gr. 5. L. 15., "Grækenland-Tyrkiet: Politiske Forhold," Pakke 1, Juni 1914-31/12 1945, nr. 13, 9 June 1914.

93. UM, Gr. 5. L. 15., "Grækenland-Tyrkiet: Politiske Forhold," Pakke 1, Juni 1914-31/12 1945, nr. 41, 27 June 1914. See also Akçam, From Empire to Republic, 145-46.

94. UM, Gr. 139, Afd. D. 1., "Tyrkiet-Indre Forhold," Pakke 1, til 31 dec. 1916, nr. CXXV, 22 September 1915; Yair Auron, The Banality of Indifference: Zionism and the Armenian Genocide (New Brunswick, NJ: Transaction Publishers, 2000), 64-65. See also Peter Balakian, The Burning Tigris: The Armenian Genocide and America's Response (New York: HarperCollins, 2003), 284. American sources report that outside Palestine, Ottoman Jews were generally not systematically persecuted during the Armenian genocide, but they also report exceptions to that rule: Sarafian, United States Official Records, e.g., 122-23, 208, 265, 351, 494, 581. Plans for deporting thousands of Jews from Palestine were initiated by Djemal Pasha in the spring of 1917, sparking fears that the Ottoman Jews would meet a fate similar to that of the Armenians, but once again, American and European protests forced the authorities to cancel the plans: Auron, Banality of Indifference, 73.

95. Quoted in Ara Sarafian and Eric Avebury, eds., British Parliamentary Debates on the Armenian Genocide, 1915-1918 (Princeton, NJ: Gomidas Institute, 2003), 19. See also Balakian, Burning Tigris, 284. On Ottoman Jewish fears, see Yair Auron, "Zionist and Israeli Attitudes toward the Armenian Genocide," in In God's Name: Genocide and Religion in the Twentieth Century, ed. Omer Bartov and Phyllis Mack, 267-88 (New York: Berghahn Books, 2001), 273.

96. UM, Gr. 139, Afd. D. 1., “Tyrkiet-Indre Forhold," Pakke 1, til 31 dec. 1916, nr. CXXIV, 16 June 1916.

97. UM, Gr. 139, Afd. D. 1., "Tyrkiet-Indre Forhold," Pakke 1, til 31 dec. 1916, nr. CXXV, 22 September 1915; UM, Gr. 139, Afd. D. 1., "Tyrkiet-Indre forhold," Pakke 1, til 31 dec. 1916, nr. CVIII, 8 May 1916. On the general efforts by Jewish populations during World War I to support the countries they lived in, see Auron, Banality of Indifference, 60.

98. One example is the establishment of an "underground railway" that, through bribery and close cooperation between Dersim Kurds and Western missionaries in Harput and Mezreh, succeeded in smuggling a large number of Armenians into safety in the Dersim area and further on to the Caucasus: e.g., Jacobsen, Maria Jacobsen's Diary, 345-46, 440-42, 461-62; James L. Barton, comp., "Turkish Atrocities": Statements of American Missionaries on the Destruction of Christian Communities in Ottoman Turkey, 1915-1917 (Ann Arbor, MI: Gomidas Institute, 1998), 44, 47.

99. See, e.g., Niepage, Rædslerne i Aleppo, 20. Some 100,000-200,000 Christian Armenian women and children were forcibly and systematically assimilated, however, rather than killed: Ara Sarafian, "The Absorption of Armenian Women and Children Into Muslim Households as a Structural Component of the Armenian Genocide," in In God's Name: Genocide and Religion in the Twentieth Century, ed. Omer Bartov and Phyllis Mack, 209-21 (New York: Berghahn Books, 2001), 210. This is one of the major points that separates the Armenian genocide from the quintessential "total genocide," the Holocaust, in which possibilities of conversion or "Germanization" did not exist as even a theoretical means of survival for Jews. It must also be noted that Turkification by conversion and assimilation as a means of survival for Ottoman Armenians was extremely brutal, as well as conditional: the alternative was almost certain death; only a limited number of Armenians were allowed to convert; with few exceptions, they had to be women or children; they had to become Muslims; they had to "become Turks" by completely dissociating themselves from anything "Armenian"; they were often sexually abused, used as slaves, and so on in Muslim households. Thus, the Armenian genocide was total in the sense that the killing of more than a million Armenians was supplemented by the attempted complete destruction of "Armenianness" in the Ottoman Empire: see, e.g., Matthias 
Bjørnlund, “'A Fate Worse Than Dying': Sexual Violence during the Armenian Genocide” (paper presented at War and Sexuality in Twentieth Century Europe conference, Esbjerg, Denmark, 28 June-1 July 2006).

100. David McDowall, A Modern History of the Kurds (London: I.B. Tauris, 2000), 102-9.

101. George E. White, "Some Non-conforming Turks," Moslem World 8.3 (1918): 242-48, 248, quoted in Hans-Lukas Kieser, "Some Remarks on Alevi Responses to the Missionaries in Eastern Anatolia (19th-20th cc.)," Columbia International Affairs Online (CIAO)

Working Papers, March 2001, http://www.hist.net/kieser/pu/responses.html (accessed 23 December 2005). On the persecutions of Ottoman Arabs, see Wandel's report of a conversation with the former governor of Lebanon, Yussuf Pacha Franco: UM, Gr. 139, Afd. D. 1., "Tyrket—Indre Forhold," Pakke 1, til 31. dec. 1916, nr. CLXXXXVIII, 16 December 1915, as well as Wandel's account of the forced starvation of the Lebanese population: UM, Gr. 139, Afd. N. 3., "Syrien," nr. LXXXVII, 31 May 1917. See also UM, Gr. 139, Afd. D. 1., "Tyrkiet-Indre Forhold," Pakke 2, jan. 1917-1. jan 1919, nr. IV, 6 January 1916.

102. The Young Turks' common use of the phrase "military necessity" to excuse or explain their exterminatory policies was just as commonly and explicitly dismissed by first-hand witnesses: see, e.g., Niepage, Rædslerne i Aleppo, 3-4; Morgenthau, 10 July 1915, in Sarafian, United States Official Records, 51-52.

103. UM, Gr. 139, Afd. D. 1., "Tyrkiet-Indre Forhold," Pakke 1, til 31 dec. 1916, nr. XCVII, 14 August 1915. On the xenophobic policy of the CUP, see also UM, Gr. 139, Afd. D. 1., "Tyrkiet-Indre Forhold," Pakke 1, til 31 dec. 1916, nr. LXX, 3 July 1915.

104. UM, Gr. 139, Afd. D. 1., "Tyrkiet-Indre Forhold," Pakke 1, til 31 dec. 1916, nr. CXIII, 4 September 1915.

105. See also UM, Gr. 139, Afd. N. 1., "Armenien," nr. LIV, 10 March 1916.

106. UM, Gr. 139, Afd. D. 1., "Tyrkiet-Indre Forhold," Pakke 1, til 31 dec. 1916, nr. CXIII, 4 September 1915.

107. UM, Gr. 139, Afd. D. 1., "Tyrkiet-Indre Forhold," Pakke 1, til 31 dec. 1916, nr. CXIII, 4 September 1915. See also Leslie A. Davis, The Slaughterhouse Province: An American Diplomat's Report on the Armenian Genocide, 1915-1917 (New York: Aristide D. Caratzas, 1989), 70, 158; Sarafian, United States Official Records, 639.

108. UM, Gr. 139, Afd. D. 1., "Tyrkiet-Indre Forhold," Pakke 1, til 31 dec. 1916, nr. CXIII, 4 September 1915. See also Jacobsen, Maria Jacobsen's Diary, e.g., 829-30; Morgenthau, Ambassador Morgenthau's Story (2003 ed.), 215; Adalian, "American Diplomatic Correspondence," 155, 158; James Bryce and Arnold Toynbee, The Treatment of Armenians in the Ottoman Empire, 1915-1916, uncensored, ed. Ara Sarafian (Princeton, NJ: Gomidas Institute, 2000), 57.

109. On deportations from Constantinople, see also Vahakn N. Dadrian, "The Comparative Aspects of the Armenian and Jewish Cases of Genocide: A Sociohistorical Perspective," in Is the Holocaust Unique? Perspectives on Comparative Genocide, ed. Alan S. Rosenbaum, 101-35, (Boulder, CO: Westview Press, 1996), 109.

110. UM, Gr. 139, Afd. D. 1., "Tyrkiet-Indre Forhold," Pakke 1, til 31 dec. 1916, nr. CXIII, 4 September 1915.

111. Ibid. The view that the Catholic Armenians were particularly apolitical and "loyal" was shared by Austrian ambassador Pallavicini: Artem Ohandjanian, 1915: Irrefutable Evidence. The Austrian Documents on the Armenian Genocide, rev. ed., trans. Tigran Tsulikian (Yerevan: National Academy of Sciences, 2004), 60.

112. Hilmar Kaiser, At the Crossroads of Der Zor: Death, Survival, and Humanitarian Resistance in Aleppo, 1915-1917 (Princeton, NJ: Gomidas Institute, 2002), 10.

113. UM, Gr. 139, Afd. D. 1., "Tyrkiet-Indre Forhold," Pakke 1, til 31 dec. 1916, nr. CXXXVIII, 3 October 1915. See also Dadrian, History of the Armenian Genocide, 221-22.

114. UM, Gr. 139, Afd. D. 1., "Tyrkiet-Indre Forhold," Pakke 1, til 31 dec. 1916, nr. CXXXVIII, 3 October 1915. See also UM, Gr. 139, Afd. D. 1., “Tyrkiet-Indre Forhold,” Pakke 1, til 31 dec. 1916, u. nr., 25 November1915. 
115. Dadrian, History of the Armenian Genocide, 231, n. 18.

116. However, Wandel does mention Rahmy Bey, World War I vali of Smyrna, as another highlevel, but less vocal, opponent of the genocide: e.g., UM, Gr. 139, Afd. D. 1., "Tyrkiet-Indre Forhold," Pakke 1, til 31 dec. 1916, nr. CXV, 9 September 1915.

117. Akçam, From Empire to Republic, 75, 83-84.

118. E.F. Knight, The Awakening of Turkey (London: Milne, 1909), 84ff, quoted in Arpee, History of Armenian Christianity, 292.

119. UM, Gr. 139, Afd. D. 1., "Tyrkiet-Indre Forhold," Pakke 1, til 31 dec. 1916, nr. CLXXIII, 14 December 1916.

120. On Riza's criticism of Western imperialism, see Hanioglu, Preparation for a Revolution, e.g., 35-36.

121. UM, Gr. 139, Afd. D. 1., "Tyrkiet-Indre Forhold," Pakke 1, til 31 dec. 1916, nr. XXIII, 10 March 1915; UM, Gr. 139, Afd. D. 1., "Tyrkiet-Indre Forhold," Pakke 1, til 31 dec. 1916, nr. CXXV, 23 September 1915; Vahakn N. Dadrian, "Genocide as a Problem of National and International Law: The World War I Armenian Case and Its Contemporary Legal Ramificications," Yale Journal of International Law 14 (1989): 221-334, 267-68.

122. UM, Gr. 139, Afd. D. 1., "Tyrkiet-Indre Forhold," Pakke 2, nr. CLXXV, 20 December 1917.

123. UM, Gr. 139, Afd. D. 1., "Tyrkiet-Indre Forhold," Pakke 1, til 31 dec. 1916, nr. LV, 10 March 1916.

124. Dadrian, "Genocide as a Problem," 268.

125. UM, Gr. 139, Afd. D. 1., "Tyrkiet-Indre Forhold," Pakke 2, nr. CLXXV, 20 December 1917. Note how Ahmed Riza explicitly highlights "political necessity," not "military necessity," as the Young Turks' motive for the "deportations." On the subject of official Young Turk genocide denialist publications, what Riza dismissively calls "brochures," see especially UM, Gr. 139, Afd. N. 1., "Armenien," nr. LXXXII, 4 April 1916.

126. Quoted in Dadrian, History of the Armenian Genocide, 224. See also Kaiser, Imperialism, Racism, 25, n. 46. For Danish eyewitnesses to the actual implementation of the "confiscations" in the Mamouret-ul-Aziz and Diyarbekir regions, respectively, see Jacobsen, Maria Jacobsen's Diary, 405-406; Hansine Marcher, Oplevelser Derovrefra (Copenhagen: KMA, 1919), 16-17. 


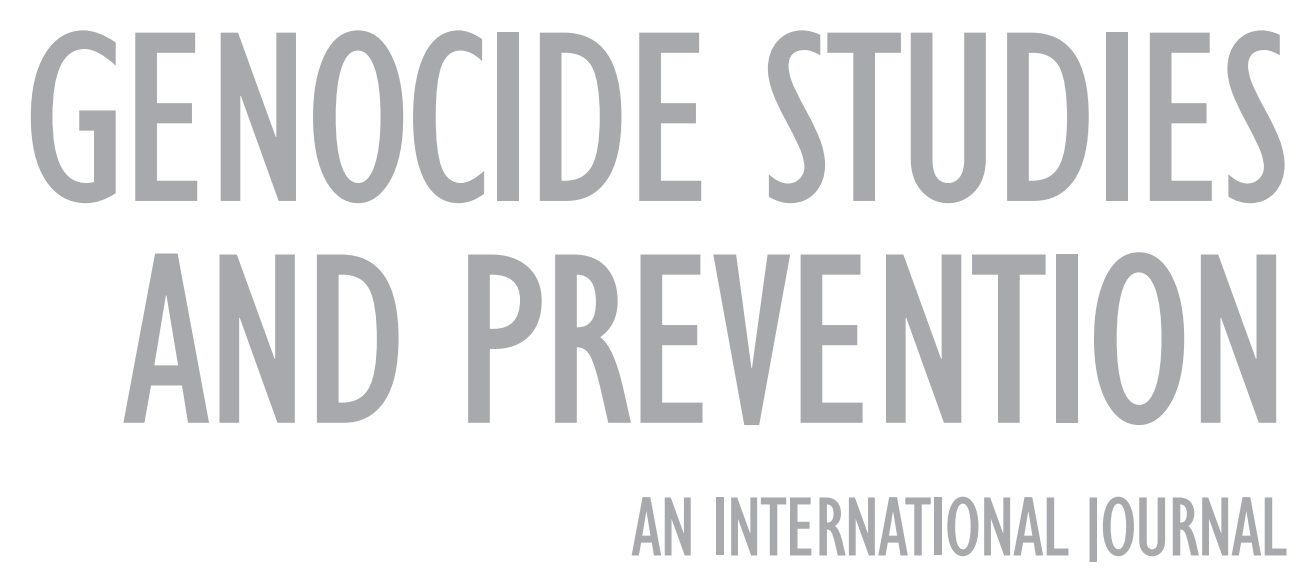

